\title{
MODEL KURIKULUM KOMPETENSI BERPIKIR PADA PEMBELAJARAN BAHASA INDONESIA DI PERGURUAN TINGGI VOKASI
}

\author{
Zulmy Faqihuddin Putera dan Nurul Shofiah \\ Teknik Sipil, Politeknik Negeri Malang \\ Email: zulmyfaqihuddin@polinema.ac.id,nurulshofiah@uin-malang.ac.id
}

\begin{abstract}
Abstrak
Kompetensi berpikir meru pakan aspek penting yang harus dimiliki oleh mahasiswa baik pergunan tinggi voka sional maupun non vokasional. Pengimplementasian kemampuan berpikir dapat melalui pembelajaran matakuliah yang dila kukan. Bahasa indonesia yang merupakan m a takulia h wajib yang harus dibelajarkan di perguruan tinggi memiliki relevansi terkait internalisa si ko mpe te nsi berpikir kepada mahasiswa. Relevansi mataku liah Bahasa sebagai sa rana bagi mahasiswa unruk mengungkapkan pikiran sebagai bentuk kemampuan berpikir melalui kompetensi berbahasa secara lisan maupun tu lis sesuai den gan kaidah yang berlaku. Mahasiswa mengembangkan ke mampuan berpikir dengan cara mengeksplorasi teks dalam kehidupan akademik, mendesain proposal penelitian dan kegiatan, melaporkan hasil penelitian dan kegiatan, serta mengaktualisa sikan diri dalam karya tulis ilmiah. Na mun peningkatan kompetensi berpikir mahasiswa perlu adanya model pengemban gan kurikulum kemampuan berpikir pembelajaran Bahasa Indon esia di pergu ruan tinggi voka si. Adanya pengembangan modelkurikulum tersebut bertujuan menghasilkan alternatif model kurikulum khususnya untuk matakuliah Bahasa Indonesia pada pergu ruan tinggi vokasi yang inovatif serta sesuai dengan capaian profil lulusan yang diharapkan. Adapun model kurikulum yang sesuai diterapkan dalam pendidikan vokasi a dalah modelkurikulum pembeajaran bahasa Indonesia berbasis kompetensi. Cirikhas pendidikan vokasi terle tak pada praktik. Ini berarti diperlukan pembelajaran y ang menghubungkan dengan pengalaman kehidupan nyata. Pada da sarnya semua pendekatan pembelajaran yang menghubungkan dengan pengalaman kehidu pan nya ta merupakan elemen pembelajaran berbasis konteks.
\end{abstract}

Kata kunci: kompetensiberpikir, pembelajaran bahasa indonesia, vokasi.

\section{PENDAHULUAN}

Matakuliah Bahasa Indonesia berdasarkan UUPT No. 12/2012 Pasal 35 ayat 1 merupakan matakuliah wajib yang harus diberikan pada program diploma maupun sarjana di Pendidikan vokasi (Dirjen Belmawa, 2016). Relevansi matakuliah Bahasa Indonesia pada Pendidikan vokasi tentu saja bukan hanya terkait kewajiban yang tertera di undang-undang saja namun juga sebagai sarana bagi mahasiswa unruk mengungkapkan pikiran sebagai bentuk kemampuan berpikir melalui kompetensi berbahasa secara lisan maupun tulis sesuai dengan kaidah yang berlaku. Adapun tidak berhenti hanya di situ saja melainkan melalui Bahasa Indonesia, mahasiswa mengembangkan kemampuan berpikir dengan cara mengeksplorasi teks dalam kehidupan akademik, mendesain proposal penelitian dan kegiatan, melaporkan hasil penelitian dan kegiatan, serta mengaktualisasikan diri dalam karya tulis ilmiah.

Di Indonesia, peningkatan mutu Pendidikan merupakan salah satu prioritas utama kegiatan Pendidikan. Hal tersebut telah berulang kali diusahakan melalui berbagai kegiatan.
Diantaranya meingkatkan kemampuan tenaga pengajar yang mengacu pada dua kemampuan pokok yaitu kemampuan terhadap bidang ajaran dan kemampuan mengelola proses belajar mengajar (Furqon, Muhaimin, \& Maimun, 2005).

Dengan substansi kajian pada setiap matakuliah wajib dalam kurikulum dapat dikembangkan oleh dosen sesuai dengan perkembangan zaman dan keilmuan maka perlu adanya model kurikulum pengembangan kemampuan berpikir pembelajaran Bahasa Indonesia di perguruan tinggi vokasi. Adanya pengembangan model kurikulum tersebut bertujuan menghasilkan alternatif model kurikulum khususnya untuk matakuliah Bahasa Indonesia pada perguruan tinggi vokasi yang inovatif serta sesuai dengan capaian profil lulusan yang diharapkan.

Apa yang diajarkan berkaitan dengan matakuliah yang akan dibelajarkan, sedang bagaimana membelajarkannya berkaitan dengan strategi pembelajaran. Kedua hal tersebut adalah dua hal yang saling berkaitan, sehingga keduanya harus berjalan seimbang dan selaras. Upaya untuk meningkatkan "apa yang dibelajarkan" 
menuntut adanya kemampuan untuk Menyusun suatu kurikulum yang relevan dengan perkembangan dan tuntutan zaman. Untuk itu, kurikulum harus mampu mengakomodasikan semua informasi dan kebutuhan kekinian.

Adapun Perguruan tinggi vokasi memiliki peran sangat strategis dalam menyiapkan generasi muda untuk memiliki pengetahuan, keterampilan dan karakter yang unggul sehingga menjadi tenaga kerja yang siap terjun di dunia industri atau usaha bahkan wiraswastawan. Perguruan tinggi vokasi dalam menyelenggarakan pendidikannya berlandaskan kepada regulasi pendidikan Indonesia. Demikian pula, dalammendisain dan mengimplementasikan kurikulumnya perlu memperhatikan ketentuan yang berlaku di Indonesiaagar senantiasa relevan dengan konteks Nasional Indonesia, namun berwawasan global.

Pada masa awalnya pendidikan tinggi vokasi dimaksudkan untuk menjembatani (interface) Insinyur dan Operator. Pendidikan tinggi vokasi belum secara spesifik menjawab tantangan bangsa yang berkembang saat ini. Pendidikan tinggi vokasi mengambil peran dalam menghasilkan lulusan kompeten dengan kualifikasi yang cocok dengan tantangan yang dihadapi bangsa Indonesia. Pendidikan tinggi vokasi mampu secara tepat mengidentifikasi kebutuhan di lingkungannya dan menyiapkan proses pembelajaran yang menjamin lulusannya dapat menjawab tantangan tersebut.

Mengacu pada uraian tersebut, model kurikulum kompetensi berpikir kritis pada pembelajaran bahasa Indonesia selanjutnya membahas a) model kurikulum, b) model pengembangan kurikulum, c) keterampilan berpikir, dan d) pembelajaran bahasa di perguruan tinggi vokasi.

\section{PEMBAHASAN}

\section{Model Kurikulum}

Kurikulum didefinisikan sebagai suatu usaha dari institusi pendidikan untuk membawa hasil yang diinginkan di dalam institusi pendidikan maupun di luar situasi institusi pendidikan. Atau rangkaian pengalaman potensial yang diberikan di institusi pendidikan dengan tujuan untuk mendisiplinkan peserta didik dengan jalan berpikir dan bertindak.

Dengan demikian, kurikulum harus mengembangkan komitmen terhadap pembelajaran sebagaimana mendorong dan menstimulasi kemajuan dan pencapaian tertinggi bagi peserta didik. Kurikulum seharusnya membangun kekuatan, minat, dan pengalaman serta mengembangkan keyakinan diri mereka di dalam kemampuan mereka untuk belajar dan bekerja secara independen dan kolaboratif. Kurikulum juga seharusnya membekali terhadap peserta didik kemampuan pembelajaran esensial dalam hal menulis dan membaca, menghitung, serta teknologi informasi dan komunikasi, dan mendorong pemikiran kritis dan kapasitas berpikir secara rasional.

Pengembangan kurikulum
istilah komprehensif yang
perencananan
mencakup perencanaan, penerapan, dan penilaian. terhadap perubahan dan perbaikan. Sehingga pengembangan kurikulum terkadang disamakan dengan perbaikan kurikulum. Meskipun dalam bebebrapa kasus, perbaikan itu merupakan akibat dari pengembangan (Olivia, 1992: 26). Menurut Ruhimat dkk (2009) menyatakan bahwa model pengembangan kurikulum merupakan suatu alternatif prosedur dalam rangka mendesain (designing), menerapkan (implementation), dan mengevaluasi (evaluation) suatu kurikulum. Oleh karena itu, model pengembangan kurikulum harus dapat menggambarkan suatu proses sistem perencanaan pembelajaran yang dapat memenuhi berbagai kebutuhan dan standar keberhasilan Pendidikan

Berdsarkan pernyataan tersebut dapat disimpulkan bahwa model pengembangan kurikulum adalah model yang digunakan untuk mengembangkan suatu kurikulum dengan mendesain, menerapkan, dan mengevaluasi yang dibutuhkan untuk memperbaiki atau menyempurnakan kurikulum yang dibuat untuk dikembangkan sendiri baik dari pemerintah pusat, pemerintah daerah atau institusi pendidikan.

Terdapat banyak model pengembangan kurikulum yang dikembangkan oleh para ahli. Sukmadinata (2005:161) menyebutkan delapan model pengembangan kurikulum yaitu: the administrative (line staff), the grass roots, Bechamp's system, The demonstration, Taba's inverted model, Rogers interpersonal relations, Systematic action, dan Emerging technical model.

\section{Model Pengembangan Kurikulum}

Hilda Taba dalam bukunya yang berjudul Curriculum Development Theory and Practice (1962) mengungkapkan pendekatannya untuk 
proses pengembangan kurikulum. Tujuan utama model ini yakni pengembangan ketrampilan berpikir kritis peserta didik.

Model Taba berorientasi pada pendekatan proses. Taba berkontribusi terhadap tiga pemikiran, yakni: (1) kebutuhan akan metode untuk menilai pembelajaran bermakna yang melampaui ujian dan perolehan muatan.(2) perencanaan kurikulum yang terkoordinasi dengan kelompok organisasi, dan (3) Dosen berkolaborasi dalam menghubungkan mata pelajaran institusi pendidikan dengan aktivitas untuk menyepakati tema- tema yang canggih( Jhon, 2009: 365) Model kurikulum Taba memodifikasi model dasar kurikulum Tyler agar lebih representative terhadap pengembangan kurikulum di berbagai institusi pendidikan. modifikasi tersebut terutama penekanannya pada pemusatan perhatian dosen. Taba mempercayai bahwa dosen merupakan faktor utama dalam usaha pengembangan kurikulum. Dosen harus aktif penuh dalam pengembangan kurikulum. Pengembangan kurikulum yang dilakukan dosen dan memposisikan dosen sebagai inovator dalam pengembang kurikulum merupakan karakteristik dalam model pengembangan Taba.

Dalam model pengembangan kurikulum, Hilda Taba juga menggalakkan untuk menggunakan pertimbangan terhadap isi kurikulum dan individu pelajar. Pelaksanaan kurikulum diawali dengan mendiagnosis keperluan pelajar agar kurikulum selaras dengan pengalaman pelajar kerena melibatkan kriteria dari berbagai sumber seperti tradisi, tekanan social, dan kebiasaan. Model kurikulum Taba menekankan cara untuk meneguhkan kecerdasan mental dan proses berfikir dengan menganalisis informasi dan konsep.

Model pengembangan kurikulum Hilda Taba, sering disebut sebagai model terbalik. Dikatakan terbalik karena model ini merupakan cara yang lazim ditempuh secara deduktif sehingga model ini sifatnya lebih induktif. Model ini dimulai dengan melaksanakan eksperimen, diteorikan, kemudian diimplementasikan. Hal ini dilakukan untuk menyesuaikan antara teori dan praktik, serta menghilangkan sifat keumuman dan keabstrakan kurikulum, sebagaimana sering terjadi apabila dilakukan tanpa kegiatan eksperimental.

Hilda Taba (1962: 347) mengembangkan lima langkah dalam kurikulum secara berurutan sebagai berikut.

\section{1) Kelompok dosen terlebih dahulu menghasilkan unit-unit kurikulum untuk dieksperimenkan}

Pengajar menyusun unit untuk melakukan studi tentang hubungan teori dan praktek. Oleh kerena itu, diperlukan (1) Perencanaan yang didasarkan atas teori yang kuat (2) Eksperimen didalam kelas yang dapat menghasilkan data empiris untuk menguji landasan teori yang digunakan. Hasil dari langkah ini berupa unit pembelajaran yang masih bersifat draft yang siap diuji pada langkah berikutnya. Unit eksperimen ini dirancang melalui delapan kegiatan sebagai berikut:

a) Diagnosing needs. Tenaga pengajar mengidentifikasi masalah-masalah, kondisi, kesulitan serta kebutuhan-kebutnhan siswa dalam suatu proses pengajaran. Lingkup diagnosis tergantung pada latar belakang program yang akan direvisi, termasuk di dalamnya tujuan konteks di mana program tersebut difungsikan

b) Formulating Specific Objectives. Formulasi tujuan-tujuan khusus, sebagai penjabaran dari tujuan umum yang dirumuskan berdasarkan kebutuhan-kebutuhan yang telah diidentifikasi yang menjadi titik berat pada teaching leaming unit. Namun demikian tidak semua tujuan khusus tersebut dapat tercapai oleh masing-masing imit.

c) Selecting Content. Pemilihan isi (materi) berdasarkan kesepadanan dengan tujuan khusus, dan harus mempertimbangkan tingkat validitas dan signifikannya. Karena itu perlu dilakukan seleksi terhadap tingkatan isi (materi) yang meliputi pemilihan topik utama, pemilihan ide-ide dasar dan pemilihan materi khusus.

d) Organizing Content. Pengorganisasian materi dilakukan berdasarkan tingkat kemampuan awal serta minat siswa. Pengorganisasian isi disusun dari konkrit ke abstrak dan dari mudah ke sulit.

e) Selecting Learning Experiences (Activities). Pengalaman belajar disusun dengan maksud terjadi interaksi antara siswa dan materi pelajaran. Karena setiap materi memiliki beberapa fimgsi tertentu, maka perlu dilakukan penyeleksian pengalaman belajar dengan memperhatikan hal-hal sebagai berikut:

(1) Apakah kegiatan sesuai untuk mempelajari ide-ide utama?

(2) Apakah kegiatan dapat mencapai tujuan teaching learning unit? 
(3) Apakah kegiatan efesien untuk melayani lebih dari satu tujuan?

(4) Apakah kegiatan dapat meningkatkan kegiatan belajar?

(5) Apakah kegiatan dapat mengembangkan keterampilan siswa?

f) Organizing Learning Experiences Activities. Pengalaman belajar siswa disusun dan diorganisasikan dengan sekuensi dan organisasi materi (content). Kegiatan belajar siswa diarahkan dari induktif ke generalisasi dan abstraksi serta difokuskan pada pengembangan ide-ide utama, langkahlangkah perolehan konsep dan perilaku yang baik.

g) Evaluating. Evaluasi dilakukan untuk mengetahui tingkat pencapaian tujuan unit oleh siswa. Hasil evaluasi berguna untuk menentukan tujuan, diagnosis kesulitan belajar, serta penilaian dalam rangka pengembangan dan revisi kurikulum.

h) Checking for Balance and Seguence. Setelah garis besar teaching leaming dirancang lengkap, selanjutnya perlu dicek konsistensi antara semua bagian yang berkenaan dengan keseimbangan dan urutan topik-topik yang telah tersusun atau unsur-unsur dalam unit tersebut.

\section{2) Menguji unit Eksperimen}

Teaching-learning units yang dihasilkan pada langkah pertama perlu diujicobakan di kelaskelas eksperimen pada berbagai situasi dan kondisi belajar. Pengujian dilakukan untuk mengetahui tingkat validitas dan keyakinan terap bagi tenaga pengajar yang berbeda- beda gaya mengajar dan kemampuan melaksanakan pengajaran unit. Hasil uji coba menjadi masukan bagi penyempumaan draf kurikulum.

\section{3) Revisi dan Konsolidasi}

Revisi dan penyempumaan draf teaching learning units dilakukan berdasarkan data dan informasi yang terkumpul selama langkah pengujian. Pada langkah ini dilakukan pula penarikan kesimpulan (konsolidasi) tentang konsistensi teori yang digunakan. Langkah ini

dilakukan bersama oleh koordinator kurikulum dan ahli kurikulum. Produk langkah ini berupa teaching leaming units yang telah teruji di lapangan. Bila hasilnya sudah memadai, maka unit-unit tersebut dapat disebarkan dalam lingkup yang lebih luas.

\section{4) Pengembangan keseluruhan kerangka kurikulum (Developing a Framework)}

Apabila dalam kegiatan penyempurnaan dan konsolidasi telah diperoleh sifatnya yang lebih menyeluruh atau berlaku lebih luas, hal itu harus dkaji oleh para ahli kurikulum. Ada beberapa pertanyaan yang perlu dijawab dalam langkah ini; (1) apakah lingkup isi telah memadai; (2) apakah isi telah tersusun secara logis; (3) apakah pembelajaran telah memberikan peluang terhadap pengembangan intelektual, keterampilan, dan sikap; (4) dan apakah konsep dasar sudah terakomodasi.

\section{5) Implementasi dan Desiminasi}

Instalasi dan desiminasi adalah peresmian dan penyebarluasan kurikulum hasil pengembangan, sebagai sub sistem pada sistem institusi pendidikan secara menyeluruh. Tanggung jawab tahap ini dibebankan pada administrator institusi pendidikan. Penerapan kurikulum merupakan tahap yang ditempuh dalam kegiatan pengembangan kurikulum. Pada tahap ini harus diperhatikan berbagai masalah : seperti kesiapan tenaga pengajar untuk melaksanakan kurikulum di kelasnya, penyediaan fasilitas pendukung yang memadai, alat atau bahan yang diperlukan dan biaya yang tersedia, semuanya perlu mendapat perhatian dalam penerapan kurikulum agar tercapai hasil optimal

Dalam garis besarnya langkah-langkah dalam model Hilda Taba (dalam Sukiman, 2013:100) dapat dijelaskan sebagai berikut.

1) Menentukan tujuan pendidikan, dengan langkah-langkah yakni: merumuskan tujuan umum, mengklasifikasi tujuan-tujuan, merinci tujuan-tujuan berupa pengetahuan (fakta ide, konsep), berpikir, nilai-nilai dan sikap, emosi dan perasaan, keterampilan.

2) Merumuskan tujuan dalam bentuk yang spesifik. Mengidentifikasi dan menyeleksi penglaman belajar, dengan langkah- langkah: mengidentifikasi minat dan kebutuhan pelajar, menentukan keluasan dan kedalaman pembelajaran, menentukan keseimbangan antara ruang lingkup dan kedalaman

3) Mengorganisasikan bahan kurikulum dan kegiatan belajar.langkah-langkaynya yakni, menentukan organisasi kurikulum, menentukan urutan atau sequence materi kurikulum, melakukan pengintegrasian kurikulum, dan menentukan fokus pelajaran

4) Mengevaluasi hasil pelaksanaan kurikulum. Langkah-langkahnya yakni menentukan 
kriteria penilaian, menyusun program evaluasi yang komprehensif, teknik pengumpulan data, interpretasi data evaluasi, menerjemahkan evaluasi ke dalam kurikulum

Menurut Hilda Taba teori perkembangan kurikulum bukan hanya membatasi persoalan perkembangan kurikulum, melainkan juga menguraikan sistem konsep yang harus digunakan untuk menilai hubungan kurikulum ini terhadap pendidikan. Perkembangan kurikulum adalah usaha yang kompleks yang melibatkan berbagaimacam keputusan. Berbagai keputusan itu dibuat mengenai tujuan umum yang hendak pendidikan atau (institusi pendidikan) itu raih dan tujuan pelajaran yang lebih spesifik. Bidang utama atau mata pelajaran di dalam kurikulum harus diseleksi.

\section{Keterampilan Berpikir}

Kompetensi berpikir merupakan kemampuan dalam menggabungkan sikap-sikap, pengetahuan, dan keterampilan-keterampilan yang memungkinkan seseorang untuk dapat membentuk lingkungannya agar lebih efektif. Selanjutnya, Wilson (2000) mengemukakan bahwa kemampuan berpikir merupakan bagian dari intelektual manusia dalam proses kognitif. Kemampuan berpikir didefinisikannya sebagai keterampilan kognitif yang memungkinkan seseorang untuk memahami informasi, menerapkan pengetahuan, mengekspresikan konsep yang kompleks, mengkritik, merevisi sesuai hasil konstruksi, memecahkan masalah, serta membuat keputusan.

Terkait domain kognitif tersebut, Bloom (Anderson dan Krathwohl, 2010) mengidentifikasi ada dua kategori kemampuan berpikir, yaitu kemampuan berpikir tingkat rendah dan kemampuan berpikir tingkat tinggi. Kemampuan berpikir tingkat rendah umumnya hanya difokuskan pada kemampuan mengingat informasi, mengumpulkan informasi, dan menjelaskan ulang suatu informasi dengan katakata sendiri. Contoh kemampuan pengetahuan dan pemahaman.

Kategori kedua dari Taksonomi Bloom yakni kemampuan berpikir tingkat tinggi. Kemampuan berpikir tingkat tinggi umumnya selalu dikaitkan dengan kemampuan berpikir yang lebih kompleks dan abstrak. Dalam aplikasinya, seseorang dapat dikategorikan memiliki kemampuan berpikir tingkat tinggijika ia mampu menghubungkan semua informasi yang dimilikinya secara komprehensif serta menggunakannya untuk membuat suatu kesimpulan. Contoh kemampuan yang tergolong kemampuan ini, yaitu: kemampuan mengaplikasi, menganalisis, mensintesis, dan mengevaluasi (mengkreasi).

Marzano (1988) berusaha menjawab permasalahan seputar taksonomi Bloom dengan membentuk suatu model taksonomi yang baru, yaitu taksonomi Marzano. Taksonomi ini menjawab keterbatasan dari taksonomi Bloom. Marzano mengembangkan model taksonomi yang memadukan faktor yang berjangkauan luas yang memengaruhi bagaimana siswa berpikir. Model taksonomi ini tidak hanya menjelaskan bagaimana siswa memutuskan apakah akan terlibat dalam tugas baru di suatu waktu, tetapi juga menjelaskan bagaimana informasi diproses setelah keputusan untuk terlibat telah dibuat. Model taksonomi Marzano memuat tiga sistem mental, yaitu sistem diri, sistem metakognitif, dan sistem kognitif. Adapun komponen keempat dari model tersebut adalah domain pengetahuan. Sistem diri memuat suatu jaringan dari keyakinan dan tujuan yang saling berhubungan yang digunakan untuk membuat keputusan tentang kelayakan keterlibatan dalam suatu tugas. Sistem metakognitif bertanggung jawab membuat tujuan yang berhubungan dengan tugas baru dan mendesain strategi untuk pencapaian tujuan yang telah dibuat. Sistem kognitif bertanggung jawab untuk memproses informasi secara efektif yang perlu untuk penyelesaian tugas. Sistem kognitif mempunyai empat level, yaitu retrieval (pemanggilan kembali), comprehension (pemahaman), analysis (analisis), dan knowledge utilization (pemanfaatan pengetahuan).

Ketiga sistem ini memerlukan domain pengetahuan yang akan memengaruhi kesuksesan siswa dalam menghadapi setiap tugas. Ketiga sistem dan domain pengetahuan dalam model taksonomi Marzano penting bagi siswa untuk berpikir dan belajar. Sewaktu berhadapan dengan pilihan untuk memulai tugas baru, sistem diri memutuskan apakah melanjutkan kebiasaan yang dijalankan saat ini atau masuk dalam aktivitas baru. Sistem metakognitif mengatur berbagai tujuan dan menjaga tingkat pencapaian tujuantujuan tersebut. Sistem kognitif memroses seluruh informasi yang dibutuhkan, dan domain pengetahuan menyediakan isinya. Secara sederhana, model dari taksonomi Marzano ini adalah tahapan-tahapan dalam berpikir dan belajar yang dimulai dari mengingat, memahami, menganalisis, dan memanfaatkan pengetahuan 
yang didapat dengan berbekal pengetahuan yang dimiliki sebelumnya.

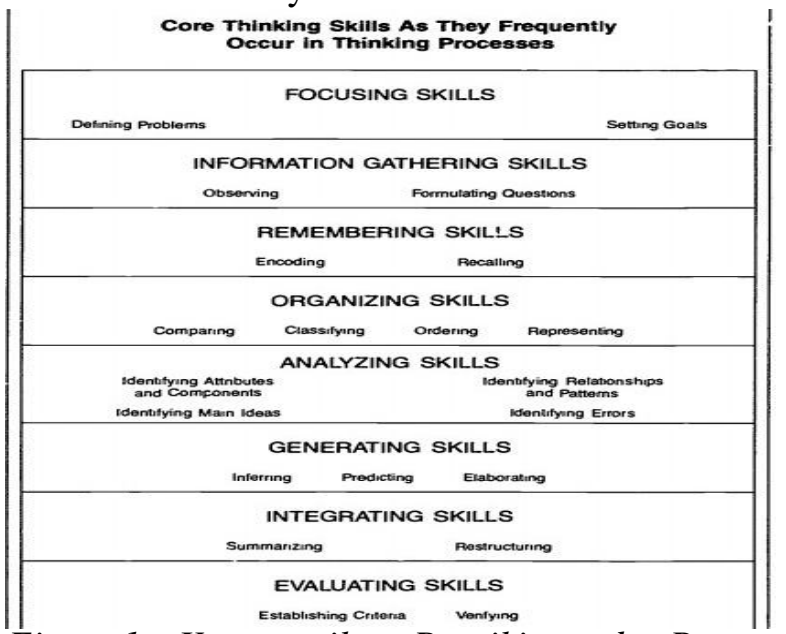

Figur 1. Keterampilan Berpikir pada Proses Berpikir Marzano

\section{Pembelajaran Bahasa di Perguruan Tinggi Vokasi}

Pendidikan vokasional merupakan bagian dari pendidikan kecakapan hidup yang mengharuskan peserta didik belajar untuk bisa. Belajar untuk bisa inilah merupakan ciri khas pendidikan vokasional. Untuk memenuhi hal tersebut, kegiatan praktik atau latihan merupakan kegiatan yang paling dominan dalam pendidikan vokasional. Teori dan praktikum diperlukan sejauh itu dapat mendukung kegiatan praktik atau latihan dalam proses pem belajarannya (Depdiknas, 2005). Pembelajaran bahasa Indonesia mendapatkan peran dalam pembelajaran di perguruan tinggi vokasi tidak hanya sebagai matakuliah wajib namun juga menginternalisasikan kemampuan berpikir kritis kepada mahasiswa dalam pembelajarannya. Kecakapan penyusunan sebuah karya tulis ilmiah baik mulai laporan praktikum, laporan bengkel, laporan praktik kerja industri, makalah, sampai pada skripsi merupakan sebagian tugas pembelajaran bahasa Indonesia kepada mahasiswa pada proses pembelajarannya. Kemampuan berpikir kritis sangat ditekankan dalam proses penyusunan karya tulis ilmiah tersebut, sehingga diharapkan mahasiswa memiliki profil lulusan nantinya yang dapat bersaing di dunia kerja. Kecakapan vokasional merupakan salah satu dari empat kecakapan hidup. Secara keseluruhan keempat aspek kecakapan hidup itu adalah kecakapan personal, kecakapan sosial, kecakapan akademik, dan kecakapan vokasional (Depdiknas, 2003).
Keempat kecakapan tersebut diklasifikasikan menjadi dua, yakni kecakapan generik yang terdiri atas kecakapan personal dan kecakapan sosial serta kecakapan spesifik yang terdiri atas kecakapan akademik dan kecakapan vokasional. Pendidikan vokasional pada dasarnya merupakan program pendidikan bidang keahlian yang diarahkan pada penguasaan praktis. Hal-hal yang bersifat teoritis diperlukan diperlukan sepanjang mendasari penguasaan praktis tersebut. Pendidikan vokasi menyiapkan peserta didiknya terampil sesuai dengan kompetensi yang sudah ditetapkan dalam kurikulum. Untuk bisa mencapai tujuan itu diperlukan banyak praktik dibanding teori. Uraian tersebut sejalan dengan pendapat Sofyan (2006:12) dan Hadi (2011) bahwa pendidikan vokasi merupakan pendidikan dengan tujuan utama mempersiapkan peserta didik untuk bekerja dengan menggunakan pendekatan pembelajaran berbasis kompetensi. Ciri khas pendidikan vokasi terletak pada praktik. Teori dan praktikum sangat diperlukan sebagai landasan pelaksanaan praktik. Pernyataan tersebut sejalan dengan pandangan Moodie (2008:15), bahwa Pendidikan vokasional adalah pendidikan untuk bekerja. Untuk mencapai tujuan itu maka diperlukan praktik yang memadai.

\section{SIMPULAN}

Megingat hal-hal di atas model kurikulum yang sesuai diterapkan dalam pendidikan vokasi adalah model kurikulum pembeajaran bahasa Indonesia berbasis kompetensi. Ciri khas pendidikan vokasi terletak pada praktik. Ini berarti diperlukan pembelajaran yang menghubungkan dengan pengalaman kehidupan nyata. Pada dasarnya semua pendekatan pembelajaran yang menghubungkan dengan pengalaman kehidupan nyata merupakan elemen pembelajaran berbasis konteks. Elemen pokok yang menjiwai pembelajarannya adalah konstruktivistik. Sedangkan elemen-elemen lain saling terkait yang dijiwai oleh elemen konstruktivistik adalah bertanyajawab, inkuiri, masyarakat belajar, penilaian berbasis kelas, dan refleksi. Jika di dalam pendidikan non vokasional lebih ditekankan pada kecakapan akademik, pendidikan berbasis vokasional lebih ditekankan kepada menghasilkan produk. Ini menjadi ciri khas bahkan menjadi salah salah satu prinsip pendidikan berbasis vokasional. 


\section{REFERENSI}

Anderson, L dan Krathwohl, D. (2010). Kerangka Landasan untuk Pembelajaran, Pengajaran dan Asesmen: Revisi Taksonomi Pendidikan Bloom. Yogyakarta: Pustaka Pelajar.

Departemen Pendidikan Nasional RI. 2003. Konsep Pendidikan Kecakapan Hidup. Jakarta: Direktorat Pendidikan Menengah Kejuruan.

Furqon, Arif., Muhaimin., \& Maimun, Agus. 2005. Pengembangan Kurikulum Berbasis Kompetensi di Perguruan Tinggi Agama Islam. Jakarta: Dirjen Kelembagaan Agama Islam

Kemenristekdikti. 2016. Panduan Penyusunan Kurikulum Pendidikan Vokasi. Jakarta: Dirjen Belmawa.

Hadi. 2011. Merancang Pembelajaran Vokasional. Makalah disampaikan dalam Konverensi Nasional Pendidikan Vokasional, Malang pada tanggal 4 Februari 2011.

Jhon D Mcneil. 2014. Contemporary Curriculum: In Thought and Action (United States of America: Jhon Wiley and Sons, 2009), h. 365.

Kemdikbud. 2013. Bahan Uji Publik Kurikulum 2013. [Online]. [24 Desember 2013.

Marzano, Robert J. 1988. Dimensions of Thinking. Virginia: Association for Supervision and Curriculum Development.

Moodie, Gavin F. 2008. From Vocational to Higher Education. England: McGrawHill House.

Olivia, P.F. 1992. Developing Curriculum. New York: Harper Collin Publisher.

Ruhimat, Toto, dkk. 2009. Kurikulum dan Pembelajaran. Bandung : Jurusan Kurtekpen.
Sofyan. 2011. Revitalisasi pendidikan Vokasional. Makalah Konverensi Nasional Pendidikan Vokasional, Malang padaa tanggal 4 Februari 2011.

Sukiman, Pengembangan Kurikulum: Teori dan Praktik pada Perguruan Tinggi.Yogyakarta: Fakultas Ilmu Tarbiyah \& Kedosenan UIN Sunan Kalijaga, 2013.

Sukmadinata, N. Sy. 2005. Pengembangan Kurikulum Teori dan Praktik, Roda, Bandung.

Taba, H. 1962. Curriculum Development. Theory and Practice. New York: Harcourt, Brace and World.

Tim BBE. 2001. Konsep Pendidikan Kecakapan Hidup (Buku I). Jakarta: Departemen Pendidikan Nasional.

Wilson, V.2000. Educational Forum on Teaching Thinking Skills. Edinburgh: Scottish. 
Volume 6 No. 1 METALINGUA

April 2021 Jurnal Pendidikan Bahasa dan Sastra Indonesia 